\title{
Integrated Hydro-Irrigation-Restoration Systems: Resolving a Wicked Problem in the Whychus Creek Watershed (Oregon, USA)
}

\author{
Edward P. Weber ${ }^{1}$ \\ ${ }^{1}$ School of Public Policy, Oregon State University, Corvallis, USA \\ Correspondence: Edward P. Weber, School of Public Policy, Oregon State University, 410 Bexell Hall, Corvallis, \\ Oregon, USA. Tel: 01-541-737-2811. E-mail: Edward.weber@oregonstate.edu
}

Received: December 23, 2016

Accepted: January 21, $2017 \quad$ Online Published: March 30, 2017

doi:10.5539/jsd.v10n2p104

URL: https://doi.org/10.5539/jsd.v10n2p104

\begin{abstract}
There is an emerging problem of water scarcity associated with the water-energy nexus that has become even more complicated, and more acute, in many rural, irrigation-dependent farming and ranching communities in arid and semi-arid regions of the western U.S. and Canada. The combination of environmental laws, growing populations, increasing demand and higher costs for energy, globalized competition for agricultural commodities, and the spectre of climate change creates a wicked problem that challenges the efficacy of traditional water rights and water delivery systems, as well as the long-term sustainability of the resource-oriented communities and ecosystems involved. How might this wicked problem be resolved such that we simultaneously have more water for streams (ecological health) and growing populations, fewer fish passage obstructions, improved economic viability for working rural landscapes, more carbon free energy, adequate water quality, and improved reliability in water delivery for all water rights holders, while respecting and keeping existing water rights intact? This research analyzes the case of the Whychus Creek watershed in Oregon (USA), where an inclusive set of stakeholders collaboratively transformed the traditional irrigation system into an integrated hydro-irrigation-restoration system more fully responsive to the many different facets of the wicked problem associated with the water-energy nexus.
\end{abstract}

Keywords: water-energy nexus, wicked problems, collaboration, watershed management, irrigation, restoration, governance, systems, rural

\section{Introduction}

\subsection{The Wicked Problem of the Water-Energy Nexus and Its Importance}

Water and energy are resources critical to human survival. Water acquisition, management, movement, distribution, purification and post-use treatment are large users of energy. At the same time, energy production consumes significant amounts of water whether it is fossil fuels, thermoelectric and nuclear power plants, solar farms, hydrological fracking, or biofuels. Traditional hydropower, with reservoirs behind dams, also consumes water through evaporation (U.S. Department of Energy [USDOE], 2014; Scott et al., 2011).

The general problem facing the water-energy nexus now in the U.S. and elsewhere is that the combination of population growth, increasing demand and higher costs for energy/electricity, and the challenge of climate change for arid to semi-arid areas in particular are likely to create an unsustainable trajectory for water consumption. This emerging problem of water scarcity associated with the water-energy nexus has become even more complicated, and more acute, in rural farming and ranching communities across the U.S. West given the incongruous mix of fully, or over-allocated water rights for streams and the application of the 1973 federal Endangered Species Act and other environmental protection measures. This is because the environmental measures typically demand that more water remains instream, meaning less is available for traditional, especially consumptive, uses such as irrigated agriculture. Moreover, the structure of "first in time, first in right" water rights in western states privilege senior water rights holders, meaning that in dry or drought years, the burden of water scarcity is borne disproportionately by junior rights holders who may not get their water. This problem of water reliability for irrigation systems is likely to be exacerbated given climate change model predictions for the arid and semi-arid regions of the U.S. West and western Canada (Kenney \& Wilkinson, 2011). In short, this wicked problem of water, water rights, energy, farmers, fish/ecology, and climate change is threatening not only our ability to restore and preserve streamflows necessary to meet ecological needs, but also the legally mandated streamflows to senior water users and the economic viability of established working rural landscapes. 


\subsection{Collaborative Governance and Wicked Problems}

How might this wicked problem be resolved such that all pieces of the puzzle benefit? In other words, how can we have more water for streams (ecological health) and growing populations, fewer fish passage obstructions, improved economic viability for farmers, more carbon free energy, adequate water quality, and improved reliability in water delivery for all water rights holders, while respecting and keeping existing water rights intact?

Addressing the individual parts of the overall, interconnected problem set is unlikely to get us all the way to such a positive sum, or win-win-win solution (Ansell \& Gash, 2008; Rittel \& Webber, 1973). Practice and theory suggest, however, that employing a collaborative partnership that takes a strategic, systems-based approach to wicked problems will increase the likelihood of creative, customized solutions that leave all participants better off than before (Weber, Lach \& Steel, 2017). This is because, among other things, collaboratives

- are better matched than traditional, fragmented (silo) bureaucratic institutions to the complexity and dynamic associated with "wicked" problems (Kettl, 2006; Thomson \& Perry, 2006; Weber \& Khademian, 2008; Innes \& Booher, 2010),

- tend to create new, more constructive, higher trust, problem-solving relationships among stakeholders with disparate interests and policy preferences (Ansell \& Gash, 2008; Weber, 2003), and

- increase the capacity of units involved in public problem solving by leveraging and catalyzing the resources of many different interdependent organizations (Ostrom, 1990; Weber, 1998).

\subsection{A Case of Collaborative Success: Creating an Integrated Hydro-Irrigation-Restoration System}

The theory of collaborative governance and the expected results are one thing. What about its practice in the real world of wicked problems, in particular the water-energy nexus problem found in so many rural western landscapes in Canada and the U.S.? To examine this puzzle, we turn to the case of 40-mile long Whychus Creek, a tributary of Oregon's Deschutes River that flows down the east side of the Cascade Mountains into the Columbia River. The Three Sisters Irrigation District (TSID), working collaboratively with the Deschutes Partnership, designed a localized response that produces the multiple benefits outlined above, including several new, localized carbon free energy sources, and that replaced a traditional water delivery (irrigation) system that was, unsurprisingly given its origin in the early $20^{\text {th }}$ century, only responsive to the economic benefits and revenue needs of the agricultural community in the area.

The first part of the article explores the Whychus Creek watershed case and the different ways in which TSID and the Deschutes Partnership came together to create an integrated hydro-irrigation-restoration system able to provide successful responses for all the major components of the wicked problem. The discussion then turns to the lessons learned, specifically how (1) the pressure to change, (2) opportunities for change, and (3) a collaborative partnership approach combined to facilitate a successful transition to the new integrated system.

\subsubsection{The Whychus Creek Watershed}

The 6.8 million acre Deschutes River Basin drains an arid, high latitude plateau in the eastern rain shadow of Oregon's Cascade Mountains. Settlement came relatively late to the Deschutes Basin due to the rugged nature of the landscape, difficulty in developing roads and rail access, limited precipitation and a short growing season. In the early part of the $20^{\text {th }}$ century, irrigation development and rail access combined to spur significant economic development in the form of large-scale irrigated agriculture and timber production, both of which would constitute the bulk of the basin's economy well into the 1960's and 1970's, when recreation began attracting visitors from Portland and the Willamette Valley of Oregon.

Following the recession of the early 1980's, the high desert plateau of central Oregon experienced an extended development boom driven by retirees and second homeowners attracted to the low humidity, temperate, sunny climate, active lifestyle and small town culture. By the mid-1990's, growth pressures, shifting community demographics, economics, and changing attitudes about natural resource issues led to the formation of several community-based conservation organizations--the Deschutes Land Trust, the Deschutes River Conservancy, and the Oregon Water Trust (they have since merged with Oregon Trout to form Freshwater Trust). Passage of the Oregon Plan for Salmon and Watersheds in 1997 led to the creation of two other community-based organizations--the Upper Deschutes Watershed Council and the Crooked River Watershed Council—devoted to restoring watershed habitat.

\subsubsection{The Start of Collaboration}

Initially, all these organizations pursued their individual missions. But the 1999 ESA listing of Deschutes River 
steelhead as threatened convinced these groups to begin collaborating in ad hoc fashion and by 2005 they had come to same conclusion: their largely separate and fragmented responses needed to be replaced by a more integrated, strategic, long-term, watershed-wide collaboration in order to successfully tackle the many interconnected, complex problems facing each watershed. In 2005, four groups-Upper Deschutes Watershed Council (UDWC), Deschutes River Conservancy (DRC), Deschutes Land Trust (DLT), Crooked River Watershed Council-formed the Deschutes Partnership (DP) with the overarching goal of habitat restoration in support of successful fish reintroduction.

The DP chose the Whychus Creek drainage, with an initial focus on Camp Polk Meadows just outside of Sisters, Oregon, and areas upstream of Camp Polk. Whychus Creek was an easy choice given that sections of the stream often were dewatered toward the end of the irrigation season in August and September. It was also driven by the fact that the channelization (i.e., straightening) of 18 miles of stream by the U.S. Army Corps of Engineers after a major flood in 1964 destroyed what had historically been one of the Deschutes River's best, most productive nursery habitats for steelhead and redband rainbow trout. Hence, the biological potential for recovering and re-establishing healthy habitat and fish populations was high.

The preference for collaboration over individualized action, however, did not occur in a vacuum. In fact, a key reason why the DP chose collaborative partnership involves the fact that Todd Reeve, the leader of the Bonneville Environmental Foundation, and Mary Voss of the National Forest Foundation facilitated the many partnership discussions during 2005 and 2006, working successfully to overcome the limited trust that existed among the groups at the time (interviews $8 / 15 / 13 \mathrm{D} ; 8 / 16 / 13 \mathrm{C} ; 9 / 18 / 13$ ). At the same time, the two facilitators were not disinterested parties. They had a strong commitment to, and stake in, helping the organizations to adopt a collaborative, holistic, long-term, integrated watershed restoration approach precisely because their home organizations (foundations) were interested in funding and testing such approaches using minimum 10-year funding commitments (interviews 9/18/13; 10/2/13; 8/15/13D). Moreover, the Bonneville Environmental Foundation's Model Watershed Program requirement that these funds would only go to groups with strategic plans replete with mid-term and long-term, measurable objectives and robust monitoring programs proved to be key in (1) winning from the Oregon Watershed Enhancement Board (OWEB) guaranteed funds of \$2M per year into the indefinite future (OWEB, 2008), and (2) convincing the technical team associated with the Pelton Dam Mitigation Fund (Note 1) to also move beyond their traditional fragmented, project-by-project approach, which resulted in over $\$ 6$ million for restoring Whychus Creek habitat and streamflows.

The Deschutes Partnership also made sure to include and collaborate with other major stakeholders on Whychus Creek restoration, including, among others, the U.S. Forest Service (the primary upstream landowner), the U.S. Bureau of Reclamation, Confederated Tribes of Warm Springs, the City of Sisters, the Deschutes County Commission, private landowners, and key state agencies such as the Oregon Water Resources Department and Oregon Department of Fish and Wildlife. But perhaps most critical to successful restoration was the collaboration with the Three Sisters Irrigation District (TSID). This is because the core restoration problem was lack of water in the creek during irrigation season, particularly late summer. Simply put, TSID and the farming community had to be part of the solution because they controlled virtually all of the water rights. And successful restoration required that a significant amount of this water be placed back into the stream and it was their instream irrigation diversions that needed to be removed in order to facilitate fish passage.

Knowing this, the Partnership also recognized a principal important to successful collaborative partnerships that the costs of providing public goods such as improved habitat and added streamflow should also be shared among beneficiaries with an interest in watershed restoration. Thus, instead of forcing all the costs onto private sector actors, in this case farmers, the DP's successful search for funding allowed for significant cost sharing to occur.

\section{Method and Research Design}

The research draws on data from 18 extensive, semi-structured, open ended interviews conducted from August through October 2013 with key stakeholders involved in the Whychus Creek watershed restoration effort. Interviewees included stakeholders from environmental groups, irrigators, farmers, elected officials, state and federal agencies, local businesses, and staff of key non-profit organizations. At least one, and in some cases two representatives from each stakeholder group were interviewed. Other data was derived from primary and governmental documents and research reports focused on Oregon watershed councils, the Whychus Creek restoration effort, and Three Sisters Irrigation District materials.

The Whychus Creek case was selected because it is a "successful" case of transformation from the old, or traditional, irrigation system common across the U.S. West to the integrated hydro-irrigation-restoration system 
that is more responsive to the many facets of the emergent water-energy nexus problem this research is focused on.

The case study approach follows the advice of King, Keohane, and Verba (1994) and accepts that rich, descriptive "case studies ... are ... fundamental to social science. It is pointless to seek to explain what we have not described with a reasonable degree of precision" (44). In short, while the data provided by the Whychus Creek water-energy nexus case does not provide definitive answers to the main research questions, they are a necessary first step for future research designed to build the kind of explanatory theory that will help us to know with greater certainty which variables matter when it comes to creating integrated hydro-irrigation-restoration systems in response to these kinds of wicked problems.

\section{Results: The New Integrated Hydro-Irrigation-Restoration System}

\subsection{Motivated Irrigators: Reaping Economic Benefits through System Modernization}

The Three Sisters Irrigation District, under the leadership of Marc Thalacker, was highly motivated to act. The 1999 ESA listing of steelhead promised to eventually strip them of control over a significant portion of their water rights if they were not proactive. Further, modernizing and making their water delivery infrastructure more efficient, hence economically viable, made sense given the fact that 45 to 55 percent of all water in the system was regularly lost to evaporation and the "leaky basalt" geology in the Whychus Creek watershed (Thalacker, 2016). Moreover, the new $\$ 50$ million pressurized, piped water delivery system, in place of 50 miles of traditional open canals, meant that irrigators, including junior water rights holders, would get their full water right, guaranteed, and in a timely manner, while also almost eliminating economic outlays for the more than 100 electric pumps used to bring water to crops. For example, under the old system a 200 acre irrigated spread would incur annualized pumping costs of roughly $\$ 20,000$. With the new infrastructure these costs dropped to almost zero. The annual electricity savings from the pressurized system currently amounts to more than 5 million $\mathrm{KwH}$, or $\$ 490,000$. (Note 2) In addition, changing over to a closed piping system "reduced TSID's liabilities of having kids fall into open canals... This helped the operations and maintenance costs to go way down in the district" (interviews 8/16/13A; 8/16/13C) (see Table 1).

\subsection{Saving Water, More Revenue, and Carbon Free Energy from Small Hydro}

Further, putting a portion of the roughly 50 percent of "saved" water back into the stream reaped significant revenues for TSID since, as the water rights holder, this meant they could lease or sell "new" water shares to willing buyers, which included the State of Oregon. Finally, the new pressurized system created opportunities for two small hydroelectric power plants and one "micro-hydro" demonstration project able to generate additional electricity at low cost, while simultaneously generating a sizable new revenue stream (see Table 1). The first small-hydro "Watson" plant, completed in 2015 , is a 700 kilowatt plant, cost $\$ 2.3$ million and generates 3.1 million $\mathrm{KwH}$ annually, or $\$ 304,000$ in equivalent value (Energy Trust 2016). Watson's cost, at $\$ 3,285$ per kilowatt is also 20 percent less than the $\$ 4,100$ national average for such conduit projects (USDOE, 2015, 22). The second plant is 350 kilowatt, and will be installed when the main canal pressurized piping system is extended to Mackenzie Reservoir in 2018. It is expected to produce roughly half the energy and revenue of the Watson plant. The micro-hydro demonstration project, to be completed in Summer 2017, consists of four micro-turbines from four different manufacturers. These micro-turbines will be installed on individual farms at the point where pressure reducing valves, which lower water pressure to fit the needs of on-farm irrigation technologies, are currently placed. The new turbines are designed to capture and use the energy from the pressure reduction process instead of wasting it, which then allows TSID and the farmers, using a net metering system, to sell the re-captured power back to the grid. The "demonstration" project will collect data to see which micro-turbines are best suited for the various different farm sites within the TSID system. Taken together, the hydropower revenues and water sales help to pay off the principal and interest on the piping system construction loans. (Note 3) 
Table 1. System responsiveness to wicked problem set, Whychus Creek

\begin{tabular}{|c|c|c|}
\hline Policy Goals & $\begin{array}{l}\text { Existing Traditional Water } \\
\text { Delivery System }\end{array}$ & $\begin{array}{l}\text { Integrated } \\
\text { Hydro-Irrigation-Restoration System }\end{array}$ \\
\hline Water Rights System, Integrity of & Yes, central to system function & Yes, integrity maintained \\
\hline Energy Production & No & Yes \\
\hline $\begin{array}{l}\text { Responsiveness to Climate Change } \\
\text { (carbon free energy source) }\end{array}$ & No & Yes \\
\hline Ecology/Fish & $\begin{array}{l}\text { No, lack of "fish friendly" screens } \\
\& \text { fish passage blocked }\end{array}$ & $\begin{array}{l}\text { Yes, screening fixed \& fish passage } \\
\text { restored }\end{array}$ \\
\hline Ecology/Adequate Streamflow & No & Yes \\
\hline $\begin{array}{l}\text { Water Quality (meeting CWA temperature } \\
\text { standards) }\end{array}$ & Problematic/ regular exceedances & Yes, in most all cases \\
\hline Riparian Zone Health & Poor & $\begin{array}{l}\text { Significant \& continuing restoration } \\
\text { progress }\end{array}$ \\
\hline $\begin{array}{l}\text { Economic Benefits, General (water to } \\
\text { support on farm revenues) }\end{array}$ & Yes, water \& agriculture revenues & Yes, water \& agriculture revenues \\
\hline $\begin{array}{l}\text { Additional Economic Benefits to Users } \\
\text { - lower energy costs } \\
\text { - } \quad \text { increased revenues from water } \\
\text { sales } \\
\text { - } \quad \text { more water to use } \\
\text { - lower liability costs }\end{array}$ & No & Yes, on all counts \\
\hline $\begin{array}{l}\text { Water } \\
\text { certainty/guaranteed delivery to all users) }\end{array}$ & $\begin{array}{l}\text { Problematic in dry and/or drought } \\
\text { years }\end{array}$ & $\begin{array}{l}\text { Yes/High, even in dry and/or drought } \\
\text { years }\end{array}$ \\
\hline
\end{tabular}

\subsection{Ecological Benefits: Restoring Instream Flows, Removing Fish Barriers, and Fish-friendly Screens}

In order to be considered successful, however, collaborative partnerships must produce mutual gain, or win-win-win, outcomes, not just economic benefits important to one of the stakeholders. In fact, the new efficiencies in TSID's irrigation system were essential to the Deschutes Partnership's overarching goal of watershed restoration for four reasons (see Table 1). First, the collaborative deal with TSID reserved half of all "saved" water, or 25 percent of the total water right being delivered, for permanent, year-round instream flows. This initial streamflow of 20 cubic feet per second (cfs) satisfied the Oregon Department of Fish and Wildlife (ODFW) mandate specifying the amount of water required to meet ecological needs. Further system efficiencies have since allowed an additional $13 \mathrm{cfs}$ of streamflow back into the creek starting in 2018 (Deschutes Partnership, 2013a). Second, the old irrigation system relied on six water diversions along Whychus Creek, each of which blocked fish passage. The pressurized pipe system allowed for all six to be removed (and they have been as of 2016). Third, at the point of diversion for the new pressurized irrigation system, TSID installed a new, state-of-the-art, $\$ 1.2$ million fish friendly screen that stops fish from getting into the system and thus complies with U.S. Endangered Species Act requirements. Fourth, the pressurized system allowed for the removal of over 100 electric-powered pumps that had been used to deliver water to farmers' fields, which necessarily removed the additional risks to small fish that come from the potential to be sucked into canals, even if the pumping systems are screened.

\subsection{Other Ecological Benefits for the Watershed}

The collaborative governance effort also succeeded in producing other significant contributions to the overall ecological health of the Whychus Creek watershed.

- Land acquisition and protection. Where significant floodplain existed, historic land uses (farming) and current trends (residential development) have severely limited the creek's access to the floodplain, all of which exacerbated the "flashiness" of the streamflow and further limits key fish habitats. Much like instream flow, failure to protect lands adjacent and/or critical to Whychus Creek restoration decreased 
the likelihood of eventual success of the restoration program. Toward this end, the Partnership, acting through the Deschutes Land Trust, was successful in protecting four high priority properties comprising over 5.5 miles and 1,731 acres along the Creek. (Note 4) An additional 3,000 acres has been protected using preserves and nine conservation easements. Another 4.5 miles of key properties along the creek are in the process of being acquired (Deschutes Partnership, 2013b).

- Habitat restoration. Steps toward habitat restoration include a multi-million-dollar project that re-established the creek in its prior "natural" path in Camp Polk Meadow, rebuilt streambanks to accommodate the new flow patterns, brought in the remnants of 180 large, downed trees for log jams and other woody debris structures to manage stream and sediment flows, restored wetlands, and planted 195,000 individual native plants and 670 pounds of native grass seed. Plant survival rates to date have been over 90 percent. The DP has an additional nine miles of restoration in the planning stages and expects that seven of these nine miles will be restored by 2020 (Deschutes Partnership, 2013a).

- Water temperature. Resident trout and steelhead are cold-water fish, requiring cool water at or below 64 degrees (F) for rearing and migration, according to the State of Oregon's temperature standard. Historically, when summer diversions are at or near their peak, the consequent lower streamflows can and do lead to temperatures in the 70 to $75+$ degree range, conditions that are lethal for fish. In seven of the eight years prior to the restoration of a minimum of $20 \mathrm{cfs}$ flow year round, Whychus Creek temperatures exceeded State standards, while in the seven year span 2008 - 2014, temperature exceedances were recorded only in 2013. (Note 5) The achievement of $33 \mathrm{cfs}$ in flow by 2020 will provide even more assurance that appropriate cold-water fish temperatures are achieved year round.

- Fish and spawning redds outcomes. More than 1.3 million steelhead fry, 14,000 steelhead smolts, 200,000 chinook salmon fry and 16,000 chinook smolts have been reintroduced into Whychus Creek since 2007. Despite these efforts, and despite the fact that fish densities (biomass) are roughly seven times higher than reported in studies prior to fish reintroduction in 2007, the Upper Deschutes Watershed Council found that as of 2015 that "study data ... cumulatively depict low juvenile abundance, low rates of spawning, and few adult returns... [Further, while] 2014 redd count numbers [of 42] were up from 2013 and 2012, [they] remained low relative to 2006-2011 counts (Mork \& Houston, 2015, 134-138).

- Fish screening. Ten of 17 areas lacking Endangered Species Act compliant screening technologies were screened by the end of 2015 , including the large $\$ 1.2$ million screen mentioned above. Most importantly, the new screens account for over 83 percent of all diverted water, up from only 0.02 percent in 2006. Future plans call for all remaining screens to be installed by 2017 (Deschutes Partnership, 2013b).

\section{Discussion: Factors Important to System Transformation}

In hundreds of rural western Canadian and U.S. watersheds located in arid and semi-arid climates there is growing pressure to change the traditional methods of water delivery in order to accommodate and respond to an ever larger list of environmental protection values and threats to the status quo. Whether it is restrictions stemming from endangered species legislation, clean water legislation temperature standards, other instream flow "preservation" needs, predicted climate change and negative effects on streamflow hydrographs and available water volumes, as well as pressure to produce more carbon free energy, proponents of change often focus their energies and solutions on individual pieces of the wicked problem puzzle. The problem is that piecemeal, fragmented approaches to wicked problems are unlikely to be effective, hence new, more holistic problem solving strategies are needed (Kettl \& Kelman, 2007; Page, 2016; Weber et al,. 2017). This is what we find in the Whychus Creek case. The Deschutes Partnership and TSID, along with other key stakeholders, demonstrate that it is possible to move from an existing traditional water delivery/irrigation system, constrained as it is in the U.S. by the prior appropriations doctrine of water rights, to an integrated "hydropower-irrigation-restoration" system capable of being responsive to all facets of the wicked problem set outlined above (Table 1).

Yet, if it were easy then there would be more such cases. As it is there are only a few integrated systems in place across the West, and their primary form is less comprehensive hydropower-irrigation only projects, whether it is under the auspices of the U.S. Department of Agriculture's Natural Resources Conservation Service, the 2013 Bureau of Reclamation Small Conduit Hydropower Development and Rural Jobs Act (aka Hydropower Development Act), or the 2013 Hydropower Regulatory Efficiency Act (HREA). This narrow scope is not 
surprising since as Krause, Koziol, and Merrill $(2016,2)$ note, laws such as HREA are "intended for small [hydro-irrigation] projects that would result in minor environmental effects (e.g., projects that involve little change to water flow and use and are unlikely to affect threatened and endangered species)."

What, then, does the Whychus Creek case teach us about how to transform an established traditional water delivery system into a fully integrated "hydropower-irrigation-restoration" system? The answer comes in three main parts: pressure to change, opportunities for change, and a collaborative partnership approach that can transform on-the-ground conditions. To the extent that all three conditions are in place, the likelihood increases of successful transition to the new integrated system.

\subsection{Pressure to Change}

Whychus Creek was clearly in degraded condition. As noted previously, in most years the creek was dry in significant stretches during the months of August and September, and even when it did not run dry, the low summer flows were often too warm and lethal to fish and other aquatic species dependent on cold water. The overall ecological problem was compounded by the fact that the Mid-Columbia steelhead runs into the Deschutes River Basin were listed as threatened in 1999 under the 1973 ESA and restoration targeted Whychus because it historically possessed the best rearing and nursery habitat in the Upper Deschutes. It is precisely these kinds of ecological deterioration that can and do trigger legal mandates for change in water management systems, whether it is the 1973 ESA, the 1972 Clean Water Act, and/or other biologically determined instream flow requirements.

The second major pressure, or incentive to change in the Whychus Creek case involved ongoing concerns with the economic viability of agricultural products as globalized competition squeezed profit margins harder by exerting downward pressure on commodity prices. Prospects for long-term economic sustainability for the irrigated farms and ranches in the Three Sisters Irrigation District could be measurably improved to the extent the inefficient, aging water delivery infrastructure could be updated and made more efficient.

\subsection{Opportunities for Change}

Despite the fact that pressure to change was critical in the Whychus Creek case, getting all the way to a new integrated system capable of addressing all elements of the wicked problem required the presence of several opportunities for change. First, and foremost, is the presence of inefficient irrigation infrastructure. This is particularly the case in watersheds where streamflow allocations are already either fully or over-allocated. This is because the environmental protection side of the integrated system equation necessarily will require more water and the primary source for that water given expected precipitation declines in future years will be from new efficiencies (i.e., less seepage and evapotranspiration) wrought from the existing infrastructure.

Second, the geophysical terrain needs to be suitable for the carbon free hydropower side of the wicked problem equation. This simply means that there needs to be enough fall, or change in elevation, to meet the energy production requirements of small hydropower plants. This is a condition that will be easily met across the majority of western watersheds with their typical elevation changes of hundreds of feet to well over a thousand feet in many cases (USDOE, 2015a). Yet because not all potential hydropower sites are created equal, successful candidate sites need to pass the basic cost-benefit test, wherein the economic returns from the new modernized irrigation and small hydro system provide sufficient returns on investment over the long term. Part of this also involves the geohydrological characteristics for a given watershed and the ways in which surface and groundwater are connected and/or will be affected by changes to water flows in both natural channels and engineered systems.

Third, the upfront capital costs are significant for the changeover to an integrated "hydropower-irrigation-restoration" system, meaning that access to the necessary capital is central. And even though TSID captured \$2.4 million in 2009 American Recovery and Reinvestment Act stimulus funds for system upgrades, two new federal laws passed in 2013 - HREA and the Hydropower Development Act — are designed to provide tens of millions in additional federal financing, accelerate regulatory permitting and, in general, create greater certainty for private investors in these small hydropower projects. Moreover, political support, and funding, is strong and is positioned to grow stronger in the future. Both 2013 federal laws passed the U.S. Senate $100-0$, while there were only a total of seven no votes in the U.S. House. This is because the small hydropower facilities that produce 1 to 20 megawatts (MW) of power that "have become especially attractive to lawmakers and developers alike because these projects use low-impact designs that have minimal cost and environmental impact compared to conventional hydropower facilities" (Krause et al., 2016, 2). 


\subsection{Transforming the On-the-Ground Conditions into Results}

The various pressures to change and opportunities for change were necessary, but not sufficient, in the Whychus Creek case. Moving the integrated project forward such that all elements of the wicked problem could be successfully tackled required that they take advantage of the existing conditions and transform them into the positive sum results reported in Table 1. Several factors stood out in the efforts to capitalize on the favorable on-the-ground conditions.

\subsubsection{Collaborative Partnership Approach}

The literature on wicked problems finds that their complexity and interconnectedness necessarily cuts across policy and legal jurisdictions, thus inevitably cutting across the interests of many different kinds of stakeholders (Weber \& Khademian, 2008). The logic of wicked problems also implies that successful problem solving, to the extent it is possible, requires a multi-faceted, integrated, or holistic approach. In this case, three of the major stakeholding organizations interested watershed restoration and fish reintroduction - the DRC, UDWC, and DLT - responded to both of these requirements. They banded together in a strategic collaborative partnership - the Deschutes Partnership — and treated the problem as holistic. In other words, they knew that successful long-term watershed restoration and fish reintroduction required more water, first and foremost, and this also meant reaching out to the Three Sisters Irrigation District given their legal control of over 90 percent of the Whychus Creek streamflow. For their part, TSID brought the small hydropower piece of the "integrated system" solution to the table as essential to their ability to create revenue for paying off the infrastructure modernization loans, which is what allowed them to put water back into the creek for fish.

\subsubsection{Cost Sharing}

Many of the goods being produced by the collaborative partnership under discussion here are public in character. This means that they bestow benefits broadly precisely because the benefits cannot be captured or divided for private gain. Water quality, land preservation, and improved fish and riparian habitat are examples of public goods. For example, when water quality is improved everyone drawing from a particular body of water gets the benefit, while everyone downstream is able to capture the "good" as well. The flip side of this coin, as applied to facilitating collaborative partnership success, is that the costs of providing such public goods should also be shared among beneficiaries, rather than forcing payment by only the private sector actors whose activities are also, in many cases, causing at least part of the overall problem.

This is because collaboratives accept that private sector producers, whatever their product, are producing goods and services that at some level also provide benefits to more than just themselves. Such benefits may come in the form of employment (more jobs), the knock on effects from economic wealth (e.g., increased tax revenues; more consumer spending by producers), or products important to human nutrition (milk, cheese, vegetables, meat, etc.). The "cost sharing" rule for successful collaboratives reflects this underlying reality. The cost sharing approach also recognizes that given how property rights and proprietary information laws work, producers have significant power and incentives to resist regulatory intervention, thus delaying and, in many cases, making regulatory schemes highly ineffective over the long run (Ansell \& Gash, 2008). This is also why, to the extent that innovative collaborative solutions make certain stakeholders better off economically relative to their existing situation, the easier it will be to sustain collaboration over time.

In the Whychus Creek case, the holistic, integrated watershed restoration approach came with significant economic costs, and necessarily involved major infrastructure changes for the local irrigation district. Just as importantly, the DP knew cost sharing was key to successful collaboration and, ultimately, restoration. "[W]ithout community buy in and without the solutions, or outcomes making sense for water users, especially farmers dependent on it for their livelihoods, we knew we weren't going to get very far" (interviews 9/5/13B; $8 / 15 / 13 \mathrm{C})$.

At the same time, the successful search for program funding (described previously) created the opportunity to offer significant cost sharing possibilities to TSID.

It created the ability to have a conversation with the Three Sisters Irrigation District about making their system more efficient by getting rid of their leaky surface ditches, piping them, delivering pressurized water to the irrigators, [which] reduc[ed] the number of [instream] diversions, and $\mathrm{ma}[\mathrm{de}]$ water diversion more efficient, ... this was all very expensive work (interview 9/17/2013). 


\subsubsection{Shared Savings (Note 6) with the Environment}

The new efficiencies reaped from the irrigation system upgrades (pressurized water in conduits) created opportunities for expanded environmental protection through sharing the water "savings" with the environment. This meant that even though the new water delivery system was providing roughly twice as much water to TSID's farmers, a significant slice — in this case half, or 25 percent of the total water being delivered — was preserved for instream flows beneficial to fish and ecology. And even with the shared savings, TSID water users still came out ahead economically of where they were prior to the irrigation upgrades. The Whychus Creek case demonstrates that, as with the growing acceptance of market-based regulatory mechanisms (e.g., emissions trading) by many environmentalists over the past 25 years, the principle of shared savings can be central to getting environmentalists on board: "[I]f industry and government are willing to include shared savings as a basic design principle, they'll see more environmentalists hopping aboard the markets[, or in this case, the integrated irrigation-hydro-restoration] bandwagon" (Weber, 1998, 121).

\subsubsection{Collaborative Capacity Builders/Leaders}

Successful collaboration requires the presence of collaborative capacity builders (CCBs). CCBs possess a keen understanding of collaboration (the philosophy and practice/process), and a reputation as fair, honest, and capable of leading a big picture approach emphasizing "all of us in it together for the common good." They are also willing to commit considerable political capital in support of collaboration and have the capacity to convince others to commit to and follow through on promises, cajole participants to stay the course when times get rough, and champion the collective, positive sum benefits of successful collaboration (LaPorte, 1996).

Although sporadic and opportunistic collaboration was occurring between DP organizations in the late 1990s, the addition of Brad Nye to the DLT in 2001 to foster more formal collaboration with other groups, and changes in leadership at the top of the UDWC in 2001 and the DRC in 2004 "kicked off the desire to collaborate" (interview 8/15/13B) in a more systematic, formal way. As one participant stated, "we wanted to find new ways to partner with others interested in the health of the river and its habitat, [along with] helping fish" (interview 9/17/2013). Another commented that: "without these guys, the new leaders at DRC and UDWC, and the two Brads [Chalfant and Nye] at DLT, there is no way we ever would have come together to restore Whychus Creek as the [Deschutes] Partnership. They breathed life into the idea of collaboration and made it clear this was central to their identities, and then they worked to convince their Boards that this [collaboration] was the best way forward" (interview 9/18/2013).

The surveys of the core participants supported this conclusion as well. When asked to name the leaders critical to the success of the collaborative Whychus Creek watershed restoration program, over 90 percent named one or more of these four leaders-Hiesler (DRC), Houston (UDWC), Chalfant (DLT), and Nye (DLT). Of equal importance was the way they accomplished their leadership; they increased collaborative problem solving capacity by negotiating in good faith and fostering improved trust to the point that all the major actors were willing to work together again on future projects (Weber \& Khademian, 2008).

As part of this, these leaders have done a good job of persuading each organization, and their Boards, of the necessity of collaboration.

They have a common vision and know how to get there, and they are results-oriented and outcome-focused... which means they don't get sidetracked by details and obstacles. This is probably the best way to keep Boards supportive — get the things done that you say you will and that everyone knows are valuable to both the Partnership and the individual organizations (interview 8/12/13).

The task of collaborative leadership within the core of the Deschutes Partnership was made easier by the fact that other key organizations in Whychus Creek efforts were exercising strong leadership essential to helping the new Partnership achieve success. All but one of the core participants named Marc Thalacker of TSID as crucial to collaboration, while a supermajority of core participants (12 of 16) also identified various USFS personnel as "knowledgeable, invested and committed," "dedicated and hard working," and otherwise central to the successes of Whychus Creek restoration (interviews 8/12/13; 8/16/13D; 10/9/13). In Thalacker's case, he was not only praised for "strong leadership," being "good at building consensus," and "the ability to move through obstacles to achieve goals," but for embracing reintroduction and restoration "as an opportunity instead of a challenge" to existing irrigation practices despite the fact that "some of his clients, his landowners, are pretty rough old cods who are pretty suspicious of all this conservation crap" (interviews 9/17/13; 8/16/13B; 9/5/13C; 10/2/13). In short, Thalacker saw an opportunity to modernize an old, inefficient irrigation system and reap the economic benefits, while simultaneously minimizing the risks to farmers inherent to the ESA listing of steelhead because 
modernization allowed the removal of over 100 unscreened irrigation pumps and all six TSID diversions on the creek.

\section{Conclusion}

Concerns over climate change and the unexploited potential of hydropower as a carbon free energy source have combined to create renewed interest in hydropower, especially small hydropower. The resurgence of hydro as a potential energy source in many parts of the western U.S. and Canada has coincided with struggling rural, agriculturally based economies, and a push by agricultural interests and small municipalities that view small hydro as a way to improve economic viability by employing existing water rights to generate a new revenue stream without harming the ability to use the same water volume for traditional irrigation, household, and industrial purposes. This has led to the passage in recent years of new federal as well as state-level legislation designed to promote new hydropower development within existing irrigation districts across the U.S. West. Moreover, the Natural Resources Conservation Service is starting to facilitate the development of integrated hydropower projects, including a \$1.8 million grant to the Colorado Department of Agriculture and its partners in 2015 to facilitate the development of integrated hydropower projects (Krause et al., 2016, 7).

Yet, the new pressure to build more hydro plants in agricultural areas necessarily is about more than just climate change, energy, and economics. Particularly in arid and semi-arid climates, in watersheds suffering environmental degradation, and in places where water allocations are close to, or at, 100 percent of available surface flows, environmental instream flow, riparian zone health, and species protection issues, among others, are typically critical parts of the larger wicked problem solving puzzle. The good news appears to be that modernizing irrigation systems, thereby ridding them of large inefficiencies, creates precisely the kinds of opportunities required to produce the kinds of positive sum outcomes that can more fully and adequately address all the components of these wicked problems using integrated "hydropower-irrigation-restoration" systems.

But it won't be easy. If we want long-term, effective solutions to these wicked problems, and not just solutions that work only for farmers, rural economies, and climate change, we need to recognize them as such and act accordingly. This means, as a burgeoning series of scholarly research and practical experiments such as Whychus Creek suggest, that collaborative partnerships and leadership capable of building collaborative capacity are likely required. It also means recognizing that not all watersheds will meet the geophysical conditions required for wicked problem solving success, but most probably will.

\section{References}

Ansell, C., \& Gash, A. (2008). Collaborative Governance in Theory and Practice. Journal of Public Administration Research and Theory, 18(4), 543-571. https://doi.org/10.1093/jopart/mum032

Deschutes Partnership. (2013a). Accomplishments: Whychus Creek. Retrieved from www.deschutespartnership.org/accomplishments/whychus-creek/

Deschutes Partnership. (2013b). 2011-2013 Biennium Report. Bend, OR: Deschutes Partnership, 99 pp.

Deschutes River Conservancy. (2013). Whychus Creek Revived Through Combined Efforts (August 15). Retrieved www.deschutesriver.org/blog/2013/08/15/whychus-creek-revived-through-series-of-restoration-projects/

Energy Trust of Oregon. (2016). Irrigation District Grows the Flow: Three Sisters Irrigation District's New Hydropower Project Improves Water Management and Quality (Portland, OR). Retrieved from http://assets.energytrust.org/api/assets/success-stories/ThreeSistersIrrigation_CS_1510_web.pdf

Innes, J. E., \& Booher, D. E. (2010). Planning with Complexity: An Introduction to Collaborative Rationality for Public Policy (1st ed.). Hoboken, NJ: Taylor and Francis.

Kenney, D. S., \& Wilkinson, R. (Eds.). (2011). The Water-Energy Nexus in the American West. Northhampton, MA: Edward Elgar Publishing. https://doi.org/10.4337/9781849809375

Kettl, D. F. (2006). Managing Boundaries in American Administration: The Collaboration Imperative. Public Administration Review, 66(s1), 10-19. https://doi.org/10.1111/j.1540-6210.2006.00662.x

Kettl, D. F., \& Kelman, S. (2007). Reflections on 21 ${ }^{\text {st }}$ Century Government Management. 2008 Presidential Transition Series, IBM Center for the Business of Government. Washington, D.C.

King, G., Keohane, R. O., \& Verba, S. (1994). Designing Social Inquiry: Scientific Inference in Qualitative Research. Princeton, NJ: Princeton University Press.

Krause, C., Koziol, E., \& Merrill, M. (2016). Incorporating Small-Scale Hydropower Projects into Our Energy 
Future. Section of Environment, Energy and Resources (American Bar Association) (Spring). Retrieved from http://www.white-jankowski.com/wp-content/uploads/2016/04/Natural-Resources-Environment.pdf

La Porte, T. (1996). Shifting Vantage and Conceptual Puzzles in Understanding Public Organization Networks. Journal of Public Administration Research and Theory, 6(1), 50-51. https://doi.org/10.1093/oxfordjournals.jpart.a024302

Mork, L., \& Houston, R. (Eds.). (2015). 2014 Whychus Creek Monitoring Report. Upper Deschutes Watershed Council (December) (Bend, Oregon), 141 pp.

Oregon Watershed Enhancement Board. (2008). OWEB: Deschutes Special Investment Partnership. Retrieved from www.oregon.gov/OWEB/pages/sip_deschutes.aspx

Ostrom, E. (1990). Governing the Commons: The Evolution of Institutions for Collective Action. New York, NY: Cambridge University Press. https://doi.org/10.1017/CBO9780511807763

Page, S. (2016). A Strategic Framework for Building Civic Capacity. Urban Affairs Review, 52(4), 439-70. https://doi.org/10.1177/1078087415596848

Rittel, H., \& Webber, M. (1973). Dilemmas in a General Theory of Planning. Policy Sciences, 4, 155-159. https://doi.org/10.1007/BF01405730

Scott, C. A., Pierce, S. A., Pasqualetti, M. J., Jones, A. L., Montz, B. E., \& Hoover, J. H. (2011). Policy and institutional dimensions of the water-energy nexus. Energy Policy, 39(10), 6622-6630. https://doi.org/10.1016/j.enpol.2011.08.013

Thalacker, M. (2016). Irrigation Chronicles: Partnerships Solve Real Irrigation System Challenges. Retrieved from http://irrigationmodernization.fcasolutions.org/stories/a-pipeline-for-the-economy/

Thomson, A. M., \& Perry, J. L. (2006). Collaboration Processes: Inside the Black Box. Public Administration Review, 66(SUPPL. 1), 20-32. https://doi.org/10.1111/j.1540-6210.2006.00663.x

U.S. Department of Energy. (2014). The Water-Energy Nexus: Challenges and Opportunities (June). Retrieved from www.energy.gov/sites/prod/files/2014/06/f16/Water\%20Energy\%20Nexus\%20Report\%20June\%202014.pd $\mathrm{f}$

U.S. Department of Energy. (2015). 2014 Hydropower Market Report. (April). Retrieved from http://www.energy.gov/sites/prod/files/2015/04/f22/2014\%20Hydropower\%20Market\%20Report_2015042 4.pdf

Upper Deschutes Watershed Council. (2012). Whychus Creek: Progress in Restoration. Retrieved from http://www.upperdeschuteswatershedcouncil.org/wp-content/uploads/2014/03/WhychusRestoreReport2013 ForWeb.pdf

Weber, E. P. (1998). Pluralism by the Rules: Conflict and Cooperation in Environmental Regulation. Washington, D. C.: Georgetown University Press.

Weber, E. P. (2000). A New Vanguard for the Environment: Grass-Roots Ecosystem Management as a New Environmental Movement. Society and Natural Resources, 13(3), 237-259. https://doi.org/10.1080/089419200279081

Weber, E. P. (2003). Bringing Society Back In: Grassroots Ecosystem Management, Accountability, and Sustainable Communities. Cambridge, MA: The MIT Press.

Weber, E. P., \& Khademian, A. M. (2008, March-April). Wicked Problems, Knowledge Challenges, and Collaborative Capacity Builders in Network Settings. Public Administration Review, 68(2), 334-349. https://doi.org/10.1111/j.1540-6210.2007.00866.x

Weber, E. P., Lach, D., \& Steel, B. (Eds.). (2017). New Strategies for Wicked Problems: Science and Policy in the $21^{\text {st }}$ Century. Corvallis, OR: Oregon State University Press.

\section{Notes}

Note 1. The Pelton Dam Mitigation Fund was set up under the Federal Energy Regulatory Commission (FERC) relicensing agreement negotiated with Portland General Electric (PGE) and the Confederated Tribes of Warm Springs (CTWS) and aimed at ensuring effective fish reintroduction. It contained over $\$ 20$ million dollars. 
Note 2. Based on the average residential rate charged in Oregon of 9.8 cents per $\mathrm{KwH}$.

Note 3. TSID secured $\$ 2.4$ million in 2009 federal stimulus money, several million from the U.S. Bureau of Reclamation's Smart Water program, \$2.3 million from the Oregon Department of Environmental Quality, and $\$ 1$ million from the Energy Trust of Oregon, while also benefitting from the lower costs accrued through a change in their construction practices (8/16/13A interview). The change in construction practices involved hiring new employees and doing the infrastructure construction tasks in-house instead of contracting out the work. The change has saved millions of dollars since, as a quasi-municipality, TSID's in-house construction projects are exempt from the 1931 federal Davis-Bacon prevailing wage mandate.

Note 4. Camp Polk Meadow Preserve (145 acres, 1.5 stream miles), Rimrock Ranch (1130 acres, 1.9 stream miles); Whychus Canyon Preserve (450 acres, 1.9 stream miles), and the Pond Addition to Camp Polk Meadow Preserve (6 acres, .25 stream miles).

Note 5. Records are from Sisters City Park in all cases. See UDWC (2012) and Mork and Houston (2015, 31).

Note 6. Kosobud, Testa, and Hanson (1993, xi).

\section{Copyrights}

Copyright for this article is retained by the author(s), with first publication rights granted to the journal.

This is an open-access article distributed under the terms and conditions of the Creative Commons Attribution license (http://creativecommons.org/licenses/by/4.0/). 